Лада Олександр Валерійович кандидат історичних наук, доцент кафедри публічного управління та адміністрування ПереяславХмельницького державного педагогічного університету імені Г. Сковороди, вул. Сухомлинського, 34, м. Переяслав, 08400, тел.: (093) 939-94-58; e-mail: alex.lada1988@gmail.com, https://orcid.org/0000-0002-8253-0114

\title{
ПРОЕКТНИЙ МЕНЕДЖМЕНТ У ПУБЛІЧНОМУ УПРАВЛІННІ: ДОСВІД США ТА ПЕРСПЕКТИВИ ДЛЯ УКРАЇНИ
}

Анотація. У статті розкрито поняття “проектний менеджмент” у сфері публічного управління. Розглянуто мережу освітніх центрів в США, які здійснюють підготовку фахівців в галузі управління. До них належать бізнес школи (Гаравардський університет та Солунська школа ділової адміністрації), освітні корпорації (АМА) та заклади освіти, створені на базі провідних міжнародних корпорацій (Дженерал Моторз).

Розкрито ключові особливості менталітету американців у контексті економічного ладу країни як фактору що вплинув на формування особливої моделі менеджменту в США. А також, окреслено ряд аспектів з історії та культури США як чинників будівництва особливого корпоративного стилю ведення бізнесу. Так, до ключових рис соціальної культури американців слід віднести наступні: бажання створювати колективний продукт 3 чітко вираженою власною позицією; мінімальна участь держави в управлінні ресурсами; непорушність приватної власності як основи економічної самостійності.

Визначено ряд проблем сучасної системи публічного управління в Україні (використання старих механізмів управління; невміння ефективно використовувати всі свої потенційні можливості в межах чинного законодавства; марнування багато часу на ведення документації, на «паперову» роботу, невміння використовувати сучасні інформаційні технології оброблення, збереження i передачі інформації; недостатня кількість фахових компетентностей у багатьох співробітників, необхідних у їхній практичній роботі; структурна та системна недосконалість у внутрішньої підпорядкованості та інформаційних потоках та ін.), а також окреслено перспективи використання інструментів проектного менеджменту в публічному управлінні за прикладом провідних країн світу, де ключове місце належить США.

Мета наукового дослідження полягає в обгрунтуванні базових категорій проектного менеджменту та його ефективності в публічному управлінні.

Ключові слова: проектний менеджмент, публічне управління, трансформації, інформаційні технології, заклади освіти, дефініція, генеза. 
Lada Oleksandr.Valeriiovych $\mathrm{PhD}$ in Historical Sciences, Assistant Professor of the department of public management and administration of Hryhorii Skovoroda University in Pereiaslav, Pereiaslav, Sukhomlynskoho St., 34; tel.: (093) 939-94-58; e-mail: alex.lada1988@gmail.com

\section{PROJECT MANAGEMENT IN PUBLIC GOVERNANCE: EXPERIENCE OF USA AND PROSPECTS FOR UKRAINE}

Abstract. The article revealed the concept of "project management" in the area of public administration. A network of educational centers in the United States that train management specialists is considered. These include business schools (Harvard University and Thessaloniki School of Business Administration), educational corporations (AMA) and educational institutions established on the basis of leading international corporations (General Motors).

The problems of the modern system of public administration in Ukraine (use of old management mechanisms; inability to effectively use all their potential within the current legislation; wasting a lot of time on record keeping, on "paper" work, inability to use modern information technologies for processing, storing and transmitting information; insufficient amount of professional competencies of many employees needed in their practical work; structural and systemic imperfection in internal subordination and information flows etc.) are identified, and the prospects of using project management tools in public administration following the example of the world's leading countries, where the key place belongs to the United States.

The key features of the American mentality in the context of the economic system of the country as a factor that influenced the formation of a special model of management in the United States are revealed. Also, a number of aspects of US history and culture as factors in building a special corporate style of doing business are outlined. Thus, the key features of the social culture of Americans include the following: the desire to create a collective product with a clear position; minimal state participation in resource management; inviolability of private property as the basis of economic independence.

The purpose of the article is to explore the basic categories of project management and its effectiveness in public administration.

Keywords: project management, public administration, transformations, information technologies, educational institutions, definition, genesis.

Постановка проблеми. Сучасний, динамічний розвиток людства формує необхідність пошуку нових підходів й стандартів реалізації поставлених завдань та цілей. Саме тому, розробка нових теоретичних інструментів таких як "публічний менеджмент", “електронне адміністрування й урядування", а також розвиток інститутів громадянського суспільства покликані актуалізувати роботу органів публічної влади.

Соціалістична концепція суспільного розвитку, в руслі якої майже століття перебувала Україна, призупинила іiі зростання та уповільнила 
співпрацю 3 сусідніми європейськими державами капіталістичного світу. Пройшовши складний шлях внутрішніх трансформацій вітчизняне суспільство поступово повертається до західноєвропейських цінностей. Це формує необхідність у нових підходах щодо організації суспільного розвитку. На зміну командним моделям управління які панували в часи Радянської України прийшли сучасні ринкові механізми, серед яких нашої уваги заслуговує “проектний менеджмент”. Варто відмітити, що “західний світ" ще наприкінці XX століття сфокусував увагу в контексті проектного менеджменту, який відобразився спочатку у бізнес-секторі, а згодом і в управлінні всім суспільством. Ось чому розвиток інститутів публічної влади, a головне їх організаційних здібностей $є$ актуальним на сучасному етапі вітчизняного державотворення.

Аналіз останніх досліджень і публікацій. До питання походження та змісту “проектний менеджмент", а також його використання в публічному управління зверталися такі вітчизняні та зарубіжні дослідники як: Азаренкова Г., Василенко В., Глубоченко К., Ілляшенко С., Кальницький А., Козаченко Т., Литвиненко Г., Олійник Р., Пономаренко О., Попова Н., Рач В., Хаджирадєва С., Шматко B., Laurence E. Lynn Jr. та ін.

Мета статті полягає в обгрунтуванні базових категорій проектного менеджменту та його ефективності в публічному управлінні.

Виклад основного матеріалу. У розрізі означеної проблеми найперше важливим є ознайомлення 3 генезою самого поняття «проект» й «проектне управління». Дослідники пов'язують виникнення поняття “менеджмент” 3 відомим американським вченим Фредеріком Уінслоу Тейлором (1856-1915), якого на той час вважали одним із найвидатніших фахівців у галузі менеджменту [1]. В той же час "менеджмент" як теоретичне інструмент управління було обгрунтовано в 1881 році Паризькою торгівельною палатою, на базі якої було відкрито першу у світі комерційну школу. Та все ж як окремий навчальний курс "менеджмент" був запроваджений в США в межах Гарварського університету та Солунської школи ділової адміністрації. Саме ці навчальні заклади й стали провідними осередками підготовки спеціалістів в управлінській сфері [2].

3 огляду на те, що США $є$ країною-лідером в галузі проектного менеджменту значний інтерес викликає іiі система підготовки управлінців. На сьогоднішній день американцями збудована така мережа закладів освіти в галузі менеджменту як:

•вищі навчальні заклади;

•міжнародні організації;

•заклади освіти на базі великих компаній.

Сучасна система освіти в США є унікальною у контексті відбору вступників та підходами до навчання. Так, Гарвардський університет не має класичних екзаменів при вступі, вони замінені на співбесіди, які подекуди тривають три-чотири години. Під час відбору вступники мають продемонструвати власні розумові здібності та загальний розвиток, а також 
надати числений пакет документів, що підтверджує їх готовність до навчання (сертифікати, дипломи, рекомендації та ін.). Слід зауважити, що перевагу надають вступнику 3 якомога більшим стажем практичної роботи. В середньому він має складати 15-20 років. Іншим "просунутим" навчальним закладом 3 огляду на підготовку управлінців $є$ Солунська школа ділової адміністрації. Вона виникла при Массачусетському технологічному інституті у 1952 році. Особливостями даного вишу є фокус не стільки на практику, як це у Гарвардській школі, а на теорію. Викладачі половину власного робочого часу витрачають на науково-дослідну роботу, через те, співвідношення кількості студентів та викладачів рівнозначне. Тобто на 500 студентів - 500 викладачів. Середній вік вступників складає 30-40 років.

Вищі навчальні заклади у США є не єдиними центрами, які здійснюють підготовку управлінських кадрів. Важливе місце належить AMA (American Marketing Association) - величезна приватна організація, створена в 1923 р. Вона спеціалізується на перепідготовці менеджерів середньої ланки. При AMА проводять тижневі й двотижневі курси. Тут викладають понад 400 спеціалістів-практиків. Також до АМА входить цілий ряд організацій Асоціація президентів фірм, Асоціація управлінців нижчої ланки, Вища школа міжнародного бізнесу.

Чільне місце у підготовці менеджерів в США належить самим підприємствам. Звичайно, що мова йде про великі організації, кількісно понад 1000 співробітників. Прикладом є “Дженерол моторз”, при якій функціонує власний навчальний заклад. Система навчання тут $є$ досить нестандартною, адже протягом двох тижнів ії студенти слухають лекції, а два наступні - працюють в межах фірми. В останній семестр студенти звільняються від роботи для написання дипломної роботи [2].

Потужна система освіти в умовах вільного ліберального ринку дозволила США зайняти місце світового лідера у сфері управління. Як зазначають теоретики менеджменту, що промислова революція розпочалася в Свропі і лише потім поширилася Америкою, тоді як революція “наукового менеджменту" відбулася в США і лише згодом вийшла за іï межі [3]. Досягнення американців у проектному менеджменті є колосальними, а тому їх досвід управління процесами, побудови моделей та систем є незамінним на шляху до власних перетворень.

Сучасний американський менеджмент базується на трьох історичних передумовах: наявність ринку, індустріальний спосіб організації виробництва та корпорація як основна форма підприємництва. В умовах вільного, некированого ринку компанії перебувають у постійному пошуку нових підходів та методів задля оптимізації внутрішніх процесів і як наслідок отримання якомога більшого прибутку. Ключовим інструментом світового прогресу є конкурентна боротьба ії учасників за ринки збуту.

Менеджмент у США є невід’ємною частиною публічного управління, яке здійснюється в тісній колаборації органів державної влади 3 суспільством, на тлі історичних та культурних традицій країни. У даному 
контексті доцільно виділити головні риси соціальної культури американців:

Перший - бажання створювати колективний продукт $з$ чітко вираженою власною позицією. Це досить добре відображено в американській моделі менеджменту зорієнтованій на корпорацію (акціонерне товариство). Слід відмітити, що бажання американців до колаборації чітко візуалізовано кількістю корпорацій в країні, учасники яких - на паритетних умовах здійснюють управління та розподіл одержаних прибутків. Вартим нашої уваги є також той факт, що учасники акціонерного товариства зберігають персональну автономію щодо власних часток і при необхідності можуть їх продати чи обміняти.

Другий - “обмежена держава”. Суть якого полягає в тому, що найменший уряд $\epsilon$ найкращим урядом. Участь держави в управлінні суспільством повинна бути мінімальною i виникати лише тоді, коли неможливо розв'язати проблему без їі участі.

Tретій - є непорушність приватної власності, як основи економічної самостійності. У даному контексті слід звернути увагу на два ключові історичні фактори, які вплинули на формування сучасної соціальної культури американців. До першої слід віднести сам економічний лад країни, в основі якого лежить капіталізм з пріоритетною роллю приватної власності. Другим не менш важливим фактором $\epsilon$ історична боротьба американського суспільства за рівність на засоби виробництва та право вільного їх використання.

Досить тривалий час вітчизняний тлумачний словник був обмежений лише поняттями “менеджмент" та “проект” і не розглядав їх комплексно. Це обумовлено історичними особливостями на тлі відсутності вільного ринку як такого в умовах Радянської України. Лише в умовах незалежності, із появою ліберальної економіки та приватної власності сформувався сучасний узагальнений підхід у вітчизняній науці до тлумачення поняття “проектний менеджмент" чи то "проектне управління". Зокрема у Вікіпедії (Вільна енциклопедія) знаходимо наступне формулювання проектного менеджменту - сфера діяльності, у процесі якої визначаються та досягаються цілі проекту при балансуванні між обсягом робіт, ресурсами (кошти, праця, час, матеріали, енергія, простір тощо), якістю та ризиками [4]. Управління проектами $є$ потужним інструментом, застосування якого $є$ універсальним, а тому використовується у проектуванні у всіх галузях. Варто відмітити, що саме завдяки проектному підходу в публічному управлінні відбувається зворотній зв'язок з населенням країни, що дає змогу значно поліпшити ефективність органів публічної влади [5].

В силу певним історичним обставинам - майже сто років командної моделі управління в умовах Радянського союзу - відірвали Україну від цивілізованого світу з ринковою моделлю організації суспільних відносин, а також потужно укорінили негативні елементи в публічному управлінні, серед яких доцільно виділити наступні: використання старих механізмів управління; невміння ефективно використовувати всі свої потенційні можливості в межах чинного законодавства; марнування багато часу на 
ведення документації, на «паперову» роботу, невміння використовувати сучасні інформаційні технології оброблення, збереження i передачі інформації; недостатня кількість фахових компетентностей у багатьох співробітників, необхідних у їхній практичній роботі; структурна та системна недосконалість у внутрішньої підпорядкованості та інформаційних потоках [6].

В той же час, сучасні суспільні виклики й внутрішні трансформації на тлі зміни зовнішньополітичного курсу в напрямку “західного світу" сформували потребу в численній переоцінці усталених цінностей й стандартів особливо в контексті проектного менеджменту в сфері публічному управлінні. Прагнення українського суспільства до поліпшення рівня життя на пряму залежить від внутрішніх реформ в країні. За останні роки вітчизняний уряд втілив низку вагомих заходів, що стимулюють органи публічної влади до переоцінки ключових завдань. Найперше мова йде про децентралізацію влади, яка передбачає передачу значних повноважень та фінансів у повноваження новоствореним громадам. Це значно активізувало суспільство та сформувало необхідність в публічному управлінні використання проектному менеджменту як потужного інструменту організації заходів на будь-якому рівні. Адже проектний менеджмент як напрям професійної управлінської діяльності містить у собі стратегічне планування, організацію, моніторингові та контрольні інструменти в ході реалізації проекту та по його завершенню.

Враховуючи необхідність уніфікації вітчизняних систем та підходів в публічному управлінні до європейських стандартів, важливим $є$ створення якісних державних та комерційних центрів обслуговування громадян. Ефективне функціонування таких установ не можливе без залучення проектного менеджменту, який сприяє швидкій та якісній роботі з постійним зв’язком з громадськістю. Важливим інструментом оптимізації виробництва в умовах сьогодення $\epsilon$ використання сучасних інформаційних технологій, що прискорює обмін інформацією, заощаджує час та поліпшує якість обслуговування. Цінним також є досвід європейців в колаборації органів публічної влади з бізнесом у спільній реалізації суспільно корисних проектів.

Висновки. Отже, на основі аналізу сучасної наукової літератури вдалося проаналізувати американський досвід проектного менеджменту в публічному управлінні. Ознайомитися з системою освіти в США у розрізі означеної проблеми. Також, у ході дослідження вдалося порівняти сучасну розгалужену мережу навчальних закладів в США, яка репрезентована не лише бізнес школами (Гаравардський університет та Солунська школа ділової адміністрації), а й освітніми корпораціями (АМА) та університетами, які функціонують на базі провідних міжнародних корпорацій (Дженерал Моторз). Дослідити головні міжнародні сучасні тренди провідних країн світу у контексті використання проектного менеджменту як ключового інструменту розробки та імплементації різного роду проектів. Виявити проблеми та недоліки в системі вітчизняного публічного управління, а також окреслити перспективність й незворотність залучення проектного 
менеджменту в діяльності органів влади на усіх рівнях.

\section{Лimepamypa:}

1. Литвиненко Г. Управління проектами: сутність та особливості застосування в освіті. Рідна школа. - 2017. - № 11-12. - C. 39-43. - URL: http://nbuv.gov.ua/UJRN/rsh_2017_11-12_9.

2. Підготовка управлінських кадрів: світовий досвід, приклади // Освіта юа. URL: https://osvita.ua/vnz/reports/management/13745/print/.

3. Юрик Н.С. Історія менеджменту: Курс лекцій. Тернопіль: ТНТУ імені Івана Пулюя, 2015 - 114.

4. Управління проєктами // Вікіпедія (вільна енциклопедія). URL: https://uk.wikipedia.org/wiki/Управління_проєктами (дата звернення 20.12.2020).

5. Козаченко Т. Публічне управління на засадах проектного менеджменту: сучасний погляд. Державне управління. - 2018. - № 2(62). - С. 50-55.

6. Чернов С. Публічне управління та адміністрування в умовах інформаційного суспільства: вітчизняний і зарубіжний досвід: монографія. [За заг. ред. С. Чернова та ін.] Запоріжжя: ЗДІА, 2016. 606 с.

7. Азаренкова Г. М. Проектний аналіз (в схемах та прикладах): навчальний посібник. К.: УБСНБУ, 2015.-338 c.

8. Василенко В. О., Шматко В. Г. Інноваційний менеджмент: навчальний посібник. Київ: ЦУЛ, Фенікс, 2003. - 440 с.

9. Ілляшенко С. М. Інноваційний менеджмент: Підручник. - Суми: ВТД “Університетська книга", 2010. - 334 с.

10. Кальницький А. Є. Проектний аналіз: навчальний посібник. - Ужгород: Видавництво УжНУ “Говерла", 2014. - 320 с.

11. Попова Н. В. Проектний аналіз: підручник. Національний автомобільно-дорожій університет. Харків: ХНАДУ, 2016. - 163 с.

12. Рач В. А. Управління проектами: практичні аспекти реалізації стратегій регіонального розвитку: навчальний посібник. К.: “К.І.С. ”, 2010. - 276 с.

13. Хаджирадєва С. К. Проектний аналіз та прийняття рішень: навчальний посібник. - Київ: Видавництво “Каравелла”, 2018. - 270 с.

\section{References:}

1. Lytvynenko H. (2017) Upravlinnia proektamy: sutnist ta osoblyvosti zastosuvannia v osviti [Project management: the essence and features of application in education]. Kyiv Ridna shkola - URL: http://nbuv.gov.ua/UJRN/rsh_2017_11-12_9.

2.Sait zhurnalu «OSVITA.YUA» [Site of journal «EDUCATION.UA»]. osvita.ua Retrieved from http://osvita.ua/vnz/reports/management/13745/ [in Ukrainian].

3. Iuryk N.Ie. (2015) Istoriia menedzhmentu [History of management]. Ternopil: TNTU imeni Ivana Puliuia [in Ukraine].

4. Vilna entsyklopediia «Vikipediia» [Open encyclopedia «Wikipedia»]. Wikipedia.org Retrieved fromhttps://uk.wikipedia.org/wiki/Управління_проєктами [in Ukrainian].

5. Kozachenko T. Publichne upravlinnia na zasadakh proektnoho menedzhmentu: suchasnyi pohliad [Public administration on the basis of project management: a modern view]. Derzhavne upravlinnia. - 2018. - № 2(62). - S. 50-55

6. Chernov S. (2016) Publichne upravlinnia ta administruvannia $v$ umovakh informatsiinoho suspilstva: vitchyznianyi $i$ zarubizhnyi dosvid [Public administration in the information society: domestic and foreign experience]. Zaporizhzhia: ZDIA [in Ukraine].

7. Azarenkova, H. M. (2015). Proektnyi analiz $v$ skhemakh ta prykladakh [Project analysis in schemes and examples]. Kyiv: UBSNBU [in Ukraine]. 
8. Vasylenko, V. O., \& Shmatko V. H. (2003) Innovatsiinyi menedzhment [Innovation management]. Kyiv: TsUL Feniks [in Ukraine].

9. Illiashenko S. M. (2013) Innovatsiinyi menedzhment [Innovation management]. Sumy: VTD "Universytetska knyha [in Ukraine].

10. Kalnytskyi A. Ye. (2014) Proektnyi analiz [Project analysis]. Uzhhorod: Vydavnytstvo UzhNU "Hoverla" [in Ukraine].

11. Popova N. V. (2016) Proektnyi analiz [Project analysis]. Kharkiv: KhNADU [in Ukraine].

12. Rach V. A. (2010) Upravlinnia proektamy: praktychni aspekty realizatsii stratehii rehionalnoho rozvytku [Project management: practical aspects of implementing regional development strategies]. Kyiv "K.I.S. [in Ukraine].

13. Khadzhyradieva S. K. (2018) Proektnyi analiz ta pryiniattia rishen [Project analysis and decision making]. Kyiv: Vydavnytstvo "Karavella" [in Ukraine]. 